powinien opierać się jedynie na słownikowym znaczeniu słowa $\pi \alpha \varrho \alpha \delta i \delta \omega \mu$, z pominięciem pełnego kontekstu jego użycia; być może dokładniejsza analiza kontekstu wskazałaby, iż czasownik ten będzie się kojarzył raczej ze zdradą, niż procedurę wydania (przekazania) sądowi. Z kolei w rozdziale trzecim: „Judasz w świetle gnozy” Autor pominął lub potraktował marginalnie kilka kwestii istotnych. Po pierwsze, nie rozwinął dostatecznie zagadnienia gnostyckiego antyjudaizmu, które powinno stanowić punkt wyjścia dla rozważań o ,gnostyckim” Judaszu. Po drugie, nie dość wyraźnie podkreślił, iż wątek Judasza pojawia się w kontekście tylko jednego gnostyckiego odłamu, co pokazują cytaty z Ireneusza (Adversus haereses I 31, 1), czy Epifaniusza (Panarion 37, 3). Po trzecie: nie skomentował wątku (należącego do gnostyckiej soteriologii) o Judaszu przyśpieszającym zbawienie, przytoczył jedynie (bez komentarza) wypowiedź Epifaniusza na ten temat (Panarion, 37, 4-5), pominął natomiast wypowiedź Pseudo-Tertuliana z Adversus omnes haereses (2), która ponadto sugeruje istnienie kultu. Po czwarte, nie uwzględnił fragmentu muzułmańskiego apokryfu Ewangelia Barnaby przedstawiającego krzyżowanie Judasza zamiast Jezusa (zob. M. Starowieyski, Judasz, historia, legenda, mity, Poznań 2006, ss. 55-62); wątek pozornej śmierci Jezusa (związany z doketyzmem) w chrystologii gnostyckiej odgrywał bowiem istotną rolę (wg karpokracjanów Jezusa zastąpił Szymon Cyrenejczyk). Ponadto kompozycja tego rozdziału wydaje się nie przemyślana: dziwi np. podrozdział „Jak robi się papirusową książkę" (przedstawia technikę robienia ksiąg papirusowych). Zarzut, jaki skierować można pod adresem trzech ostatnich rozdziałów, dotyczy niedostatecznej selekcji źródeł, z których Autor korzystał. W swojej relacji, obok dokumentów wartościowych (raporty, listy), bezkrytycznie cytuje sensacyjne informacje prasowe, co wpływa niekorzystnie na wartość przekazu.

Anna Z. Zmorzanka - Lublin, KUL

\begin{abstract}
Ks. Krzysztof BARDSKI, Stowo oczyma gołębicy. Metodologia symbolicznoalegorycznej interpretacji Biblii oraz jej teologiczne i duszpasterskie zastosowanie, Warszawa 2006, Wydawnictwo Archidiecezji Warszawskiej, ss. 298.
\end{abstract}

Ks. dr hab. Krzysztof Bardski, wykładowca na Uniwersytecie Kardynała Stefana Wyszyńskiego i Papieskim Wydziale Teologicznym w Warszawie, reprezentuje należący jeszcze do rzadkości w polskiej biblistyce nurt badań zmierzający do umiejętnego - bardzo kompetentnego, unikającego zbytniego apologetyzmu, ale równocześnie zaangażowanego - ukazania nieprzemijających walorów alegorycznej egzegezy patrystycznej i średniowiecznej oraz wyjaśnienia kierujących nią zasad. Autor zaznacza we wprowadzeniu, że „praca ta 
nie ma na celu polemiki z innymi metodami interpretacji Biblii, ani nawet promowania alegorystyki jako szczególnego sposobu czytania Pisma Świętego. Jej celem jest refleksja nad zjawiskiem hermeneutycznym, które chcąc nie chcąc zajmowało bardzo ważne miejsce w dziejach odczytywania Biblii" (s. 5). Recenzowana monografia jest więc precyzyjnie opracowanym podręcznikiem metodologii egzegezy alegorycznej, dostrzegającej w słowach całego Pisma Świętego dodatkowy, ukryty poziom znaczeń, wskazujących na Jezusa Chrystusa i pomagających człowiekowi budować swoje życie na podstawie bliskiej relacji z Bogiem.

Ks. K. Bardski dowodzi w swojej książce, zestawiając patrystyczną alegorezę ze współczesnymi kierunkami egzegetycznymi (szczególnie zwracającymi uwagę na intencje tekstu wobec odbiorców różnych epok), że egzegeza symboliczno-alegoryczna nie jest zbiorem przypadkowych i subiektywnych fantazji, ale stanowi ważne dziedzictwo Kościoła, jako interpretacja polegająca na dokonywanym $\mathrm{z}$ perspektywy wiary kojarzeniu motywów literackich tekstu biblijnego z osobą i nauczaniem Chrystusa lub z konkretną egzystencjalną sytuacją człowieka, do którego kieruje On w różnych epokach historycznych swoje słowo - zawsze to samo, choć nieskończenie bogate treściowo i w różny sposób aktualne. Takie podejście zaprasza do twórczego wysiłku w obcowaniu ze Słowem Bożym, tak jak to czyniło wielu autorów wczesnochrześcijańskich, którzy nie podważając historycznego wymiaru tekstu biblijnego, traktowali go jako punkt wyjścia dla interpretacji alegorycznej, zwanej także duchową lub mistyczną. Autor opracowania, chcąc uniknąć kontrowersji związanych z zakresem znaczeniowym powyższych terminów słusznie określa ją terminem „ponaddosłowna”, czyli taka, która wykracza poza poszukiwanie sensu bezpośrednio zamierzonego przez hagiografa i przekazanego w zapisanych przez niego słowach, z zastrzeżeniem, że chodzi tylko o taką interpretację, która dokonuje się w Kościele, zgodnie z jego Tradycją i nauczaniem Magisterium.

Opracowanie ks. Bardskiego, będące w pierwszej części poszerzonym opracowaniem fragmentów opublikowanej nieco wcześniej rozprawy habilitacyjnej (Pokarm i napój mitości. Symbolizm w ponaddostownej interpretacji Biblii w Tradycji Kościoła, Warszawa 2004, 19-163), wypełnia dotkliwą lukę w systematycznych badaniach nad metodologią symboliczno-alegorycznej interpretacji Biblii. Autor przedstawia hermeneutyczne implikacje tej metody egzegetycznej oraz ocenia możliwości ich wykorzystania we współczesnej refleksji nad tekstem biblijnym. Realizacji tych założeń służy struktura książki, którą tworzą dwie wzajemnie uzupełniające się części: 1) teoretyczna - stanowiąca poparty obfitą egzemplifikacją historyczną zarys metodologii ponaddosłownego symbolizmu biblijnego; 2) praktyczna - ukazująca możliwości zastosowania omówionej metody w różnych dziedzinach teologii (trynitologia, chrystologia, eklezjologia, teologia misji, dialog międzyreligijny, teologia duchowości) oraz w posłudze homiletycznej. Na szczególną uwagę zasługuje zebranie i omówie- 
nie kryteriów poprawnej i interpretacji symboliczno-alegorycznej Biblii oraz wskazanie niebezpieczeństw grożących przy niewłaściwym jej uprawianiu.

Monografia ks. K. Bardskiego powinna stać się obowiązkową lekturą nie tylko naukowo czynnych biblistów, patrologów, teologów duchowości i homiletów, lecz również duszpasterzy. Dzięki tej rzeczowej, erudycyjnej, ale też przystępnie i pięknie napisanej książce, mogą oni teraz lepiej poznać i zrozumieć jeden z najstarszych, najbardziej oryginalnych i twórczych nurtów egzegezy biblijnej, a także nauczyć się bezpiecznego stosowania go w praktyce kaznodziejskiej i katechetycznej, z pożytkiem duchowym dla siebie i powierzonych sobie wiernych.

Ks. Mariusz Szram - Lublin, KUL

\section{Marcin PANCERZ OFM, Christi anima apud Didymum Caecum (313-398). Dissertatio ad doctoratum in Litteris Christianis et Classicis, Romae 2007, Pontificium Institutum Altioris Latinitatis (Thesis n. 654), ss. 128.}

Myśl Dydyma Ślepego - wybitnego kontynuatora egzegezy Orygenesa zajmuje umysły patrologów wciąż jeszcze w sposób nieproporcjonalnie mniejszy, niż twórczość jego wielkiego poprzednika. Na większe zainteresowanie egzegezą Dydyma wpłynęło odkrycie w 1941 r. w Tura, w pobliżu Kairu, papirusowych kodeksów z tekstami komentarzy biblijnych, przypisywanych aleksandryjskiemu mnichowi. Drugi - obok interpretacji Pisma Świętego obszar badawczy eksplorowany we współczesnej patrologicznej literaturze zachodniej, stanowi doktryna teologiczna Dydyma, przede wszystkim kwestie trynitarne i chrystologiczne. W języku polskim pionierską i dotąd jedyną monografią poświęconą teologii Dydyma pozostaje książka ks. Bogdana Czyżewskiego - Chrystologia w „Komentarzu do Zachariasza” Dydyma Ślepego (Gniezno 1996). Nie ma natomiast polskich tłumaczeń jakichkolwiek pism aleksandryjskiego mnicha.

O. Marcin Pancerz OFM swoją rozprawą doktorską włącza się w dyskusję badaczy nad ważnym w IV wieku w chrystologii wschodniej zagadnieniem statusu i roli duszy ludzkiej Chrystusa, które w kontekście szerzącego się apolinaryzmu nie mogło pozostać dla Dydyma obojętne. Problematyka ta odgrywa doniosłą rolę w dokładnym poznaniu procesu kształtowania się nauki chrześcijańskiej o naturze ludzkiej Jezusa i jej znaczenia dla soteriologii, zwłaszcza w III i IV wieku, kiedy to po przypisaniu przez Orygenesa istotnej roli duszy Chrystusa, nastąpił okres wątpliwości wynikłych po części z Orygenesowej teorii preegzystencji dusz, po części z trudności w wyjaśnianiu sposobu zjednoczenia Bóstwa i człowieczeństwa w jednej osobie Zbawiciela, których najbardziej jaskrawymi przejawami były skrajne poglądy Ariusza i Apolinarego 